\title{
Flexural strength and reliability of highly translucent colored zirconia
}

\author{
Hyun-Jun Kong* \\ Department of Prosthodontics, College of Dentistry, Wonkwang University, Iksan, Republic of Korea
}

\begin{abstract}
Purpose: The purpose of this study was to evaluate the flexural strength and reliability of highly translucent colored zirconia for all ceramic restoration. Materials and Methods: Bar-shaped specimens $(25 \times 4 \times 2.5 \mathrm{~mm})$ were prepared from highly translucent monolithic zirconia. Three experimental groups were set up according to color (shade A0, A1, and A3). For each group, 20 specimens were prepared. Flexural strength was determined using a 3-point flexural test and results were analyzed with one-way ANOVA test. Weibull statistical analysis provided 2 parameter estimates: Weibull modulus and characteristic strength. X-ray diffraction (XRD) analysis was performed. Results: There was statistically significant difference between uncolored (Shade A0) and colored (shade A1 and A3) $(P<0.05)$, but there was no difference between colored groups $(P>0.05)$. The uncolored group had higher reliability compared with colored study groups. On x-ray diffraction analysis of each group, typical peaks of tetragonal phase appeared in all groups. Conclusion: Within the limitations of this in vitro study, coloring highly translucent zirconia had significant effect on flexural strength and reliability. Therefore, clinicians should be careful when using highly translucent colored zirconia to prevent breakage of veneering ceramic and enhance aesthetics. (J Dent Rehabil Appl Sci 2020;36(1):41-7)
\end{abstract}

Key words: zirconia; translucency; color; flexural strength

\section{Introduction}

Fixed restorations based on 3 mol \% yttrium oxide stabilized tetragonal zirconia polycrystals (3Y-TZP) have become popular because its transformation toughening ability helps prevent crack propagation by increasing localized fracture resistance. ${ }^{1}$ Notwithstanding the superior mechanical properties, the white color of zirconia restrict its use in highly esthetic areas. And that's why zirconia restorations were first introduced in prosthetic dentistry as a core material and then layered by feldspathic porcelain. However, veneer chipping has been reported as frequent complication. The natural white color of zirconia with the veneer chipping problem has led to the development

Correspondence to: Hyun-Jun Kong

Clinical Fellow, Department of Prosthodontics, College of Dentistry, Wonkwang University, 895 Muwang-ro, Iksan, 54538, Republic of Korea

Tel: +82-63-859-2929, Fax: +82-63-857-4002, E-mail: zsfvzsfv@naver.com

Received: March 1, 2020/Last Revision: March 4, 2020/Accepted: March 8, 2020 of tooth colored monolithic zirconia. ${ }^{2}$

Recently, highly translucent monolithic zirconia with various shades has been introduced to eliminate the risk of chipping and achieve more natural looking properties. ${ }^{3}$ However, using coloring metal oxide to obtain shade in 3Y-TZP has the potential to lead to crystallographic and microstructure changes that could in turn affect the mechanical properties of $3 \mathrm{Y}$ TZP. ${ }^{4}$ Previous studies have reported that there was significant difference in flexural strength between colored and uncolored zirconia.,

Fracture toughness and strength was considerably sacrificed in highly translucent zirconia. ${ }^{7}$ The processes that enhance translucency, and the added coloring elements, have been shown to affect the me-

Copyright@ 2020 The Korean Academy of Stomatognathic Function and Occlusion (c) It is identical to Creative Commons Non-Commercial License. 
chanical properties of the material. Strategies for improving the optical performance of 3Y-TZP include increasing yttria content, microstructure variation, reducing the alumina dominant and creating a nanometric microstructure. ${ }^{8}$ Even small changes in these factors can cause significant differences in the microstructural and physical properties. Nevertheless, few studies investigated the influence of shade on the physical properties of highly translucent monolithic zirconia.

Therefore, the aim of this study was to evaluate and compare flexural strength and reliability of highly translucent colored zirconia. The null hypothesis was that there is no difference in flexural strength between colored and uncolored highly translucent zirconia.

\section{Materials and Methods}

A total of 60 bar-shaped specimens $(25 \times 4 \times 2.5$ $\mathrm{mm}$ ) were milled from presintered 3Y-TZP highly translucent zirconia blocks (Razor, UNC Int., Seoul, Korea) (Fig. 1) and three experimental groups were set up according to shade. Uncolored (A0) and colored (A1 and A3) blocks were used in this study. The specimens were prepared using an electrical high precision saw (IsoMet 1000 Precision Saw, Buehler Ltd, Lake Bluff, USA) under wet conditions and washed in tap water to remove the cutting debris. After that, specimens were finished manually with a ceramic polisher (Diapol, Eve Ernst Vetter GmbH, Keltem,
Germany) with a low-speed handpiece under constant water irrigation. The dimensions of the specimens were measured with a digital caliper (SD500200PRO, Sincon Corp., Seoul, Korea).

Specimens were loaded until fracture occurred in a universal testing machine (Instron 5848, Instron Corp., Canton, USA) according to ISO 6872 and previous studies. ${ }^{911}$ The load was vertically applied with a steel knife edge rounded to a radius of $1.0 \mathrm{~mm}$, centered on the specimen, at a crosshead speed of 1.0 $\mathrm{mm} / \mathrm{min}$ (Fig. 2)

The variability of the flexural strength data was analyzed using a 2-parameter Weibull cumulative distribution function. ${ }^{12-14}$ The following equation was used to calculate the Weibull monulus:

$\operatorname{Pf}(\sigma)=1-\exp [-(\sigma / \sigma 0) \mathrm{m}]$,

where $\operatorname{Pf}(\sigma)$ is the probability of failure, $\sigma$ is the fracture strength, $\sigma 0$ is the characteristic parameter corresponding to the fracture probability of $63.2 \%$,

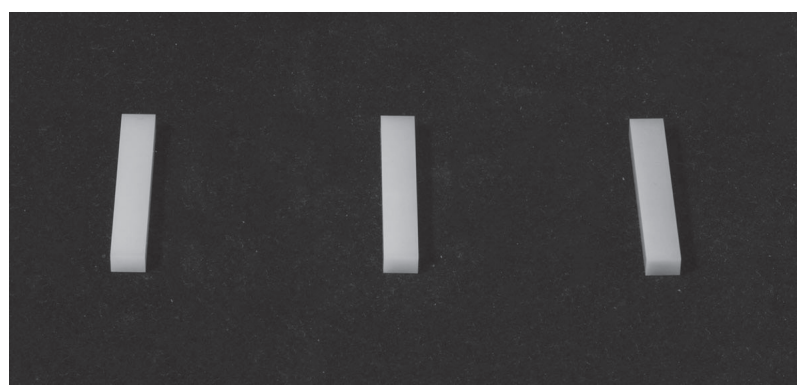

Fig. 1. Zirconia specimens used in this study (shade A0, A1, A3).
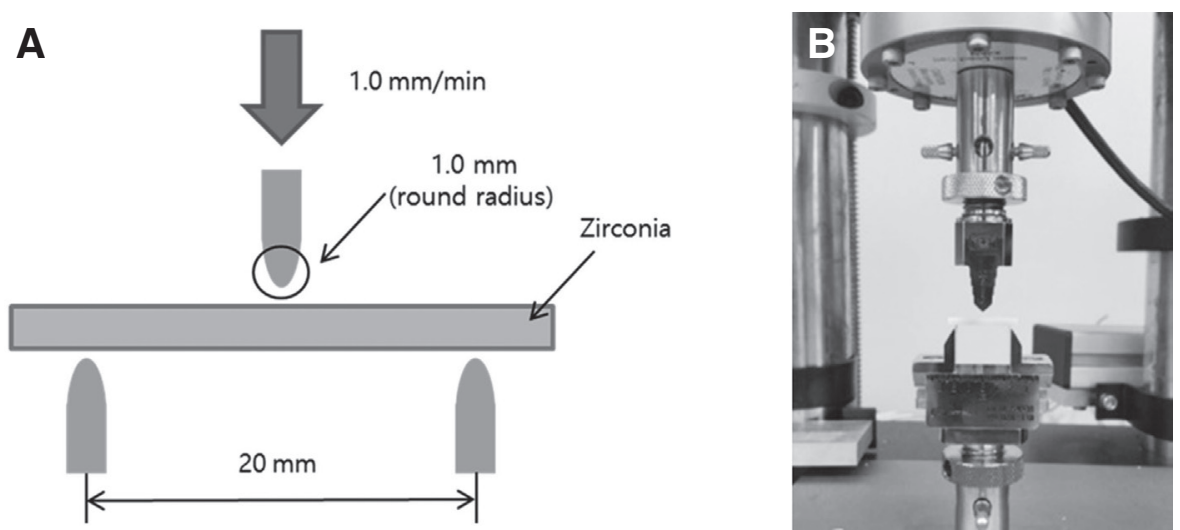

Fig. 2. 3- point flexural test. (A) Schematic diagram of specimens, (B) Universal testing machine. 
and $\mathrm{m}$ is the Weibull modulus. Weibull distribution graphs were obtained with software (Minitab ver18.0, Minitab LCC., USA).

XRD patterns were carried out by using a diffractometer (Miniflex, Rigaku Corp., USA) within the 2 $\theta$ range of 10 to 100 degrees, covering the positions of the highest peaks of tetragonal and monoclinic phases of $\mathrm{ZrO} 2$. Cuk $\alpha$ radiation was generated at $40 \mathrm{kV}$ and $40 \mathrm{~mA}$. Mass fraction of the monoclinic phase $\left(\mathrm{X}_{\mathrm{m}}\right)$ was calculated with the method suggested by Garvie and Nicholson ${ }^{15}$ :

$\left.\mathrm{X}_{\mathrm{m}}=\left(\mathrm{I}_{\mathrm{m}}[-111]+\mathrm{I}_{\mathrm{m}}[111] / \mathrm{I}_{\mathrm{m}}[-111]+\mathrm{I}_{\mathrm{m}}[111]+\mathrm{I}_{\mathrm{t}}[101]\right]\right)$, where $X_{m}$ is the mass fraction of the monoclinic phase, $I_{m}(-111)$ is the intensity of the monoclinic peak at 28.2 degrees, $I_{m}(111)$ is the intensity of the monoclinic peak at 31.5 degrees, and $I_{t}(101)$ is the intensity of the tetragonal peak at 30.2 degrees.

The volume fraction of the monoclinic phase $\left(\mathrm{V}_{\mathrm{m}}\right)$ was calculated with the method suggested by Toraya el $\mathrm{al}^{16}$ :

$\mathrm{V}_{\mathrm{m}}=1.311 \mathrm{X}_{\mathrm{m}} /\left(1+0.311 \mathrm{X}_{\mathrm{m}}\right)$,

where $V_{m}$ is the volume fraction of the monoclinic phase and $\mathrm{X}_{\mathrm{m}}$ is the mass fraction of the monoclinic phase.

Statistical analysis was performed with software (SPSS 23.0, IBM Inc., Armonk, USA). The normality of distributions was explored by Kolmogorov-
Smirnov test, and the groups were distributed normally. Flexural strength of uncolored and colored groups was evaluated with one-way ANOVA followed by the Tukey's honestly significant difference (HSD) post hoc test. Statistical significance was set at $P<0.05$.

\section{Results}

The mean of flexural strength of the three groups are presented in Table 1 . The shade A0 group showed the highest mean flexural strength compared with those of $\mathrm{A} 1$ and $\mathrm{A} 3$, and the differences were of statistical significance $(P<0.05)$. No significant difference was found between A1 and A3 $(P>0.05)$ (Table 2).

The Weibull analysis was performed to evaluate the reliability of each group (Fig. 3). A higher Weibull modulus signifies higher reliability for specimen strength. The shade A0 (12.09) study group had higher reliability compared with A1 (7.97) and A3 (7.31) study groups.

On x-ray diffraction analysis of each group, typical peaks of tetragonal phase appeared in all groups (Fig. 4). Volume fraction $\left(V_{m}\right)$ of the monoclinic phase was $2.9 \%$ for the A0 group, $3.2 \%$ for A1, and $4.6 \%$ for the A3 group.

Table 1. Mean flexural strength (in $\mathrm{MPa}$ ) for the A0, A1, A3 groups

\begin{tabular}{crrrrrrr}
\hline \multirow{2}{*}{ Group } & \multirow{2}{*}{ N } & \multirow{2}{*}{ Mean } & SD & \multicolumn{2}{c}{ 95\% CI } & \multirow{2}{*}{ Max } & \multirow{2}{*}{ Min } \\
\hline A0 & 20 & 1127.10 & 105.58 & 1064.18 & 1190.02 & 1243.36 & 788.61 \\
A1 & 20 & 995.71 & 143.25 & 932.79 & 1058.62 & 1199.93 & 740.69 \\
A3 & 20 & 1016.41 & 166.03 & 953.50 & 1079.34 & 1385.93 & 675.85 \\
\hline
\end{tabular}

Table 2. Results of Tukey's HSD post hoc test

\begin{tabular}{|c|c|c|c|c|}
\hline (I) group & (J) group & Mean difference $(\mathrm{I}$ - $\mathrm{J})$ & Standard error & Significance \\
\hline \multirow{2}{*}{ A0 } & A1 & $131.3970^{*}$ & \multirow{6}{*}{44.43473} & .012 \\
\hline & A3 & $110.6815^{*}$ & & .041 \\
\hline \multirow{2}{*}{ A1 } & A0 & $-131.3970^{*}$ & & .012 \\
\hline & A3 & -20.7155 & & .887 \\
\hline \multirow{2}{*}{ A3 } & A0 & $-110.6815^{*}$ & & .041 \\
\hline & A1 & 20.7155 & & .887 \\
\hline
\end{tabular}

* The mean difference is significant at the 0.05 level. 

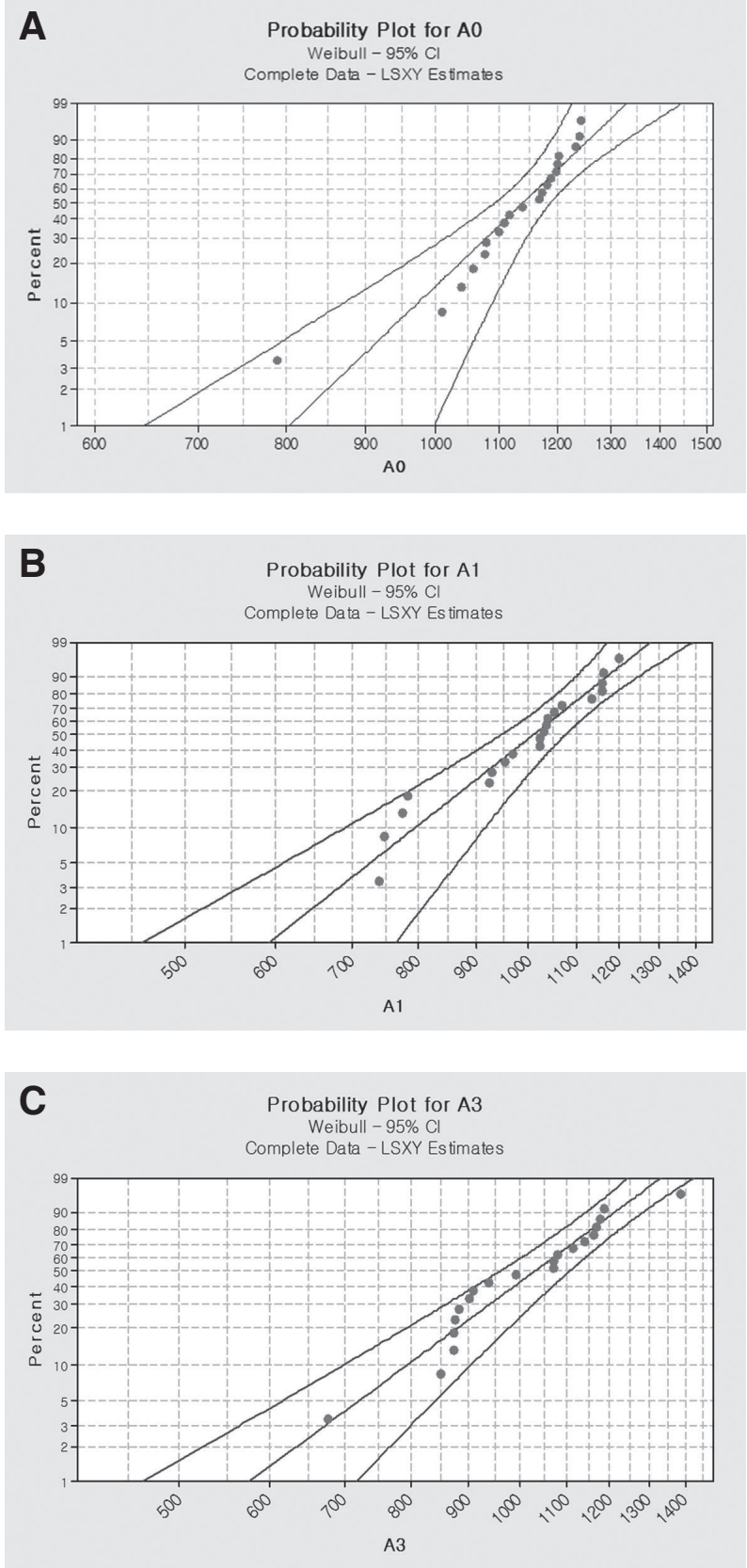

Fig. 3. Weibull distributions. Curved lines $95 \%$ confidence limits. (A) Shade A0, (B) Shade A1, (C) Shade A3.

\section{Discussion}

The present study evaluated the flexural strength and reliability of highly translucent colored zirconia. According to the results of the study, the null hypothesis that there is no difference in flexural strength between uncolored and colored zirconia was rejected.
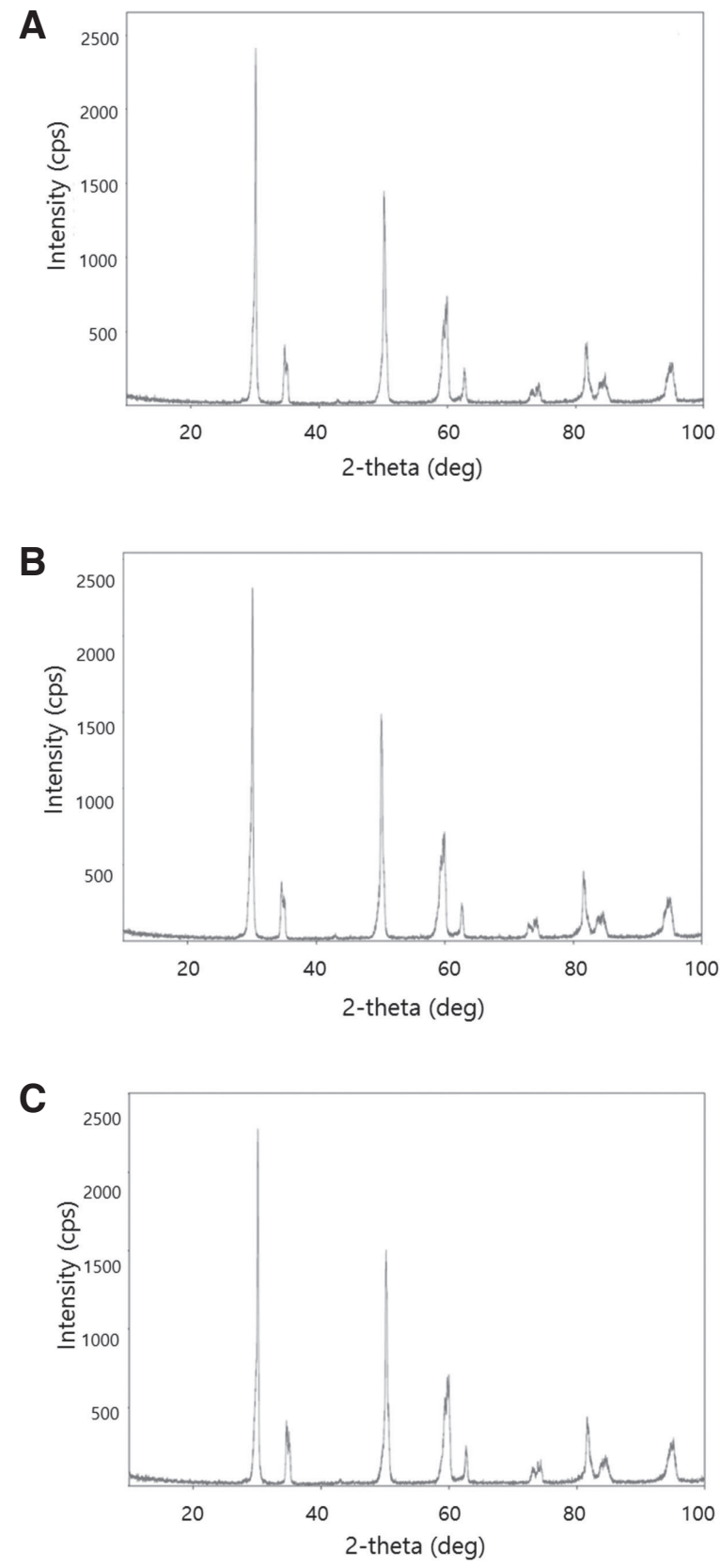

Fig. 4. X-ray diffraction peaks of zirconia specimen surface. (A) Shade A0, (B) Shade A1, (C) Shade A3.

Recently, the use of zirconia prosthesis with computer-aided design/computer-aided manufacturing (CAD/CAM) method has been increasing. Among dental ceramics, 3Y-TZP possesses excellent mechanical properties such as highest fracture resistance and fracture toughness, which contributes to its wide use in prosthodontic treatment that ranges from a single tooth restoration to full mouth rehabilitation. ${ }^{17}$ 
Moreover, it shows a more than $90 \%$ success rate in over 10-year long-term clinical studies. ${ }^{18,19}$

Factors affecting the translucency of zirconia include thickness, porosity, the density of specimen, size of the crystal, etc. It was reported that a small quantity of $\mathrm{Al}_{2} \mathrm{O}_{3}$ included in zirconia reduces the translucency due to the effect of light scattering. ${ }^{20}$ Highly translucent zirconia with more than $40 \%$ translucency used in this study did not contain $\mathrm{Al}_{2} \mathrm{O}_{3}$, and it was comparable to typical highly translucent zirconia (Lava Plus High Translucency Zirconia, 3M ESPE, Seefeld, Germany) with more than 30\% translucency.

On the flexural strength analysis using highly translucent monolithic zirconia in this study, the result of uncolored zirconia (1127.10 MPa) was significantly higher than shade A1 (995.71 MPa) and shade A3 (1016.42 MPa). Meanwhile, there was no statistically significant difference between A1 and A3. Considering that, the flexural strength of highly translucent monolithic zirconia in this experiment may be affected by coloring oxide, yet, the result of colored groups was acceptable for clinical use. ${ }^{21}$ Therefore, colored highly translucent monolithic zirconia may be used stably in a visible area requiring a high level of aesthetics.

Generally, previous studies suggested that the Weibull modulus of 5 to 15 is appropriate for dental ceramic. $^{22}$ The Weibull modulus of the specimen used in this study is between 7.31 (shade A3) and 12.09 (shade A0). These results imply that the uncolored zirconia breaks steadily and has high reliability.

Based on the results of X-ray diffraction, we concluded that the addition of coloring oxides during fabrication of highly translucent zirconia does not affect the formation of tetragonal crystal phase. The result was consistent with previous studies. ${ }^{23,24}$ The acceptable level of volume fraction of the monoclinic phase in dental zirconia is below $25 \% .^{25}$ A lot of transformations into the monoclinic phase reduces mechanical stability by time and may affect crackstopping or crack-retarding properties of zirconia. The volume fraction of the monoclinic phase in zirconia used in this study was $2.9 \%, 3.2 \%$ and $4.6 \%$ for shade A0, A1, and A3 respectively, all were within the acceptable level.

The present study measured the flexural strength and reliability of the bar-shaped specimen when a load is directed perpendicular to the long axis of the specimen. However, there is a limitation in applying the study result in clinical practice as the intraoral condition differs from the experimental environment. Therefore, future studies will need to focus on a highly translucent colored zirconia fabricated in crowns suitable for anterior, premolar, and molar region.

\section{Conclusion}

Within the limitation of the current study, the flexural strength of highly translucent monolithic zirconia was statistically significantly high in uncolored group compared with colored, but there was no significant difference between colored groups. Also, the uncolored group had higher reliability than colored study groups. Therefore, clinicians should be careful when using highly translucent colored zirconia to prevent breakage of veneering ceramic and enhance aesthetics.

\section{ORCID}

Hyun-Jun Kong https://orcid.org/0000-0001-9331-3572

\section{References}

1. Johansson C, Kmet G, Rivera J, Larsson C, Vult Von Steyern P. Fracture strength of monolithic allceramic crowns made of high translucent yttrium oxide-stabilized zirconium dioxide compared to porcelain-veneered crowns and lithium disilicate crowns. Acta Odontol Scand 2014;72:145-53.

2. Kim HK, Kim SH. Effect of the number of coloring liquid applications on the optical properties of monolithic zirconia. Dent Mater 2014;30:229-37.

3. Inokoshi M, Shimizu H, Nozaki K, Takagaki T, Yoshihara K, Nagaoka N, Zhang F, Vleugels J, Van Meerbeek B, Minakuchi S. Crystallographic and morphological analysis of sandblasted highly translucent dental zirconia. Dent Mater 2018;34:508-18. 
4. Kaya G. Production and characterization of selfcolored dental zirconia blocks. Ceram Int 2013;39: 511-7.

5. Oh SC, Lee HH, Shin MR, Lee IK. Flexural strength of various colored and uncolored zirconia ceramics for all-ceramic restoration. J Dent Rehabil Appl Sci 2007;23:119-30.

6. Hjerppe J, Närhi T, Fröberg K, Vallittu PK, Lassila LV. Effect of shading the zirconia framework on biaxial strength and surface microhardness. Acta Odontol Scand 2008;66:262-7.

7. Zhang F, Inokoshi M, Batuk M, Hadermann J, Naert I, Meerbeek BV, Vleugels J. Strength, toughness and aging stability of highly-translucent YTZP ceramics for dental restorations. Dent Mater 2016;32:e327-37.

8. Zhang Y. Making yttria-stabilized tetragonal zirconia translucent. Dent Mater 2014;30:1195-203.

9. International Organization for Standardization. ISO 6872:2008. Dentistry - Ceramic materials. Available from: https://www.iso.org/standard/41385.html (updated 2020 Mar 10).

10. Siarampi E, Kontonasaki E, Papadopoulou L, Kantiranis N, Zorba T, Paraskevopoulos KM, Koidis P. Flexural strength and the probability of failure of cold isostatic pressed zirconia core ceramics. J Prosthet Dent 2012;108:84-95.

11. Garcia Fonseca R, de Oliveira Abi-Rached F, dos Santos Nunes Reis JM, Rambaldi E, Baldissara P. Effect of particle size on the flexural strength and phase transformation of an airborne-particle abraded yttria-stabilized tetragonal zirconia polycrystal ceramic. J Prosthet Dent 2013;110:510-4.

12. Weibull W. A statistical distribution function of wide applicability. J Appl Mech 1951;18:293-7.

13. Ritter JE. Predicting lifetimes of materials and material structures. Dent Mater 1995;11:142-6.

14. Kittl P, Diaz G. Weibull's fracture statistics or probabilistic strength of materials: state of the art. Res Mechanica 1988;24:99-207.

15. Garvie RC, Nicholson PS. Phase analysis in zirconia systems. J Am Ceram Soc 1972;55:303-5.

16. Toraya H, Yoshimura M, Somiya S. Calibration curve for quantitative analysis of the monoclinictetragonal $\mathrm{ZrO}_{2}$ system by x-ray diffraction. J Am
Ceram Soc 1984;67:119-21.

17. Guess PC, Schultheis S, Bonfante EA, Coelho PG, Ferencz JL, Silva NR. All-ceramic systems: laboratory and clinical performance. Dent Clin North Am 2011;55:333-52.

18. Håff $A$, Löf H, Gunne J, Sjögren G. A retrospective evaluation of zirconia-fixed partial dentures in general practices: an up to 13-year study. Dent Mater 2015;31:162-70.

19. Stefanescu C, Ionita C, Nechita V, Drafta S, Oancea L, Petre A. Survival rates and complications for zirconia-based fixed dental prostheses in a period up to 10 years: a systematic review. Eur J Prosthodont Restor Dent 2018;26:54-61.

20. Tong H, Tanaka CB, Kaizer MR, Zhang Y. Characterization of three commercial Y-TZP ceramics produced for their high-translucency, high-strength and high surface area. Ceram Int 2016;42:1077-85.

21. Ferrario VF, Sforza C, Zanotti G, Tartaglia GM. Maximal bite forces in healthy young adults as predicted by surface electromyography. J Dent 2004; $32: 451-7$

22. Guazzato M, Quach L, Albakry M, Swain MV. Influence of surface and heat treatments on the flexural strength of Y-TZP dental ceramic. J Dent 2005;33:9-18.

23. Spyropoulou PE, Kamposiora P, Eliades G, Papavasiliou G, Razzoog ME, Thompson JY, Smith RL, Bayne SC. Composition, phase analysis, biaxial flexural strength, and fatigue of unshaded versus shaded Procera zirconia ceramic. J Prosthet Dent 2016;116:269-76.

24. Wen N, Yi YF, Zhang WW, Deng B, Shao LQ, Dong LM, Tian JM. The color of $\mathrm{Fe}_{2} \mathrm{O}_{3}$ and $\mathrm{Bi}_{2} \mathrm{O}_{3}$ pigmented dental zirconia ceramic. Key Engineering Materials 2010;434:582-5.

25. Ozer F, Naden A, Turp V, Mante F, Sen D, Blatz MB. Effect of thickness and surface modifications on flexural strength of monolithic zirconia. J Prosthet Dent 2018;119:987-93. 


\section{고반투명 유색 지르코니아의 굽힘강도와 신뢰도에 대한 연구}

\section{공현준* 전임의}

원광대학교 치과대학 치과보철학교실

목적: 본 연구의 목적은 전부도재 수복물을 위해 단일체로 사용되는 고반투명 유색 지르코니아의 굽힘강도 및 신뢰도를 평가하기 위함이다.

연구 재료 및 방법: 전부도재 수복물을 위해 사용되는 무색(A0) 및 유색(A1, A3)의 고반투명 지르코니아 블록을 사용하 여 바 형태의 시편 $(25 \times 4 \times 2.5 \mathrm{~mm})$ 을 제작하였다. 지르코니아 블록의 색조에 따라 3 개의 실험군을 설정하였고, 한 군 당 20개의 시편을 제작하였다. 굽힘강도는 3점 굽힘시험을 통해 측정하였으며, 일원배치 분산분석을 이용하여 색조에 따 른 통계적 유의성을 검증하였다. 다음으로 세라믹 재료 특성상 신뢰도를 평가하기 위해 와이블 분석을 시행하였으며, X 선 회절분석으로 시편의 결정특성을 분석하였다.

결과: 무색 고반투명 지르코니아의 굽힘강도(1127.10 MPa)가 색조 A1 (995.71 MPa)과 A3 (1016.42 MPa)에 비해 통계 학적으로 유의하게 높은 값을 보였다 $(P<0.05)$. 색조 A1과 A3 사이에는 유의한 차이가 없었다 $(P>0.05)$. 와이블 분석 을 시행한 결과, 무색 고반투명 지르코니아가 유색에 비해 높은 신뢰도를 나타냈다. X선 회절분석 결과 모든 그룹에서 지 르코니아 정방정상의 특징적인 피크를 보였다.

결론: 본 제한된 연구의 결과를 근거로 단일체로 사용되는 고반투명 지르코니아에 색조를 가미하는 것이 굽힘강도와 신 뢰도를 저하시킬 수 있으며, 도재 파절을 방지하고 심미 증진을 위해 고반투명 지르코니아를 사용할 경우 색조 선택에 주 의를 기울여야 할 것이다.

(구강회복응용과학지 2020;36(1):41-7)

주요어: 지르코니아; 반투명도; 색조; 굽힘강도

*교신저자: 공현준

(54538)전라북도 익산시 무왕로 895 원광대학교 치과대학병원 치과보철과

Tel: 063-859-2929 | Fax: 063-857-4002 | E-mail: zsfvzsfv@naver.com

접수일: 2020년 3월 1일 | 수정일: 2020년 3월 4일 | 채택일: 2020년 3월 8일 